\title{
Understanding and Nurturing Chinese Engineering Students' Critical Thinking in U.S. Universities
}

\begin{abstract}
Lei Chen*
School of international studies, Shaanxi Normal University, P.R.C.

*Corresponding author. Email: elaine_chenlei@sina.com

ABSTRACT

While it is widely believed that critical thinking is one of the most important goals in higher education for Western universities, there are discussions on whether such goal equally apply to international students, and students of different majors. Specifically, Chinese students in engineering major is widely depicted as a group of students that "lack critical thinking" in Western universities. In this project, 12 U.S. faculty and 12 Chinese undergraduate students were interviewed for their experiences teaching and learning in U.S. universities. It reveals that there is a great deal of variety among Chinese engineering students' for their purpose of studying engineering and understanding "critical thinking". Thus, they deserve to be given more attention and understanding their experiences is in need in engineering.
\end{abstract}

Keywords: Critical thinking, International students, Engineering education.

\section{INTRODUCTION}

In recent years, as a result of the booming economy in China, a growing number of Chinese students from middle-and upper-income families are seeking educational opportunities outside China. Numerous studies in education have been conducted to better understand Chinese students, for their unique cultural, social and political backgrounds, learning patterns, adaptation and academic experiences in universities abroad. (Heng, 2015; Watkins \& Biggs, 1996).

Among these studies, one of the issues that is gaining popularity in both academic field and public sphere is how the Chinese students adapt to the academic requirements in Western countries. As critical thinking is widely regarded as one of the most important goals for higher education by many Western scholars (Johnston et al, 2011), the Chinese students' development in critical thinking is under the spotlight. In this project, specifically, Chinese engineering students and U.S. engineering faculty's perspectives on critical thinking are examined. This project uses interviews to collect the data and grounded theory approach to analyze their perspectives and opinions on "critical thinking in engineering schools". The result of the study suggests that there is a great variety in faculty and students' opinions and experiences concerning "critical thinking concept". Such experience is important to understand the Chinese students as individuals with their own purpose and understanding of study in engineering major.

\section{LITERATURE REVIEW}

\subsection{Problems with Critical Thinking}

In Fox (1994), critical thinking is "more than just a set of writing and thinking techniques - it is a voice, a stance, a relationship with texts and family members, friends, teachers, the media, even the history of one's country." From 1942 to 1994, comparing Glaser and Fox, it seems that the concept of critical thinking has grown extensively from a singular purpose of citizen education, to an entity that encompasses a number of social and cultural concepts. At the same time, the previous emphasizes on democratic education in literature of critical thinking is diminished.

Despite that there are controversies in terms of the nature of the critical thinking concept per se, with the growing number of Chinese students studying abroad, both from mass media and personal encounters, some Western educators wonder whether Chinese students can demonstrate sufficient critical thinking as is required in Western universities. 
Some Chinese students themselves and literature about international education discuss that Chinese education often lacked the development of students' critical thinking (Heng, 2016; Kettle \& Luke, 2013). From the researchers' and the Chinese student's perspectives, Chinese students are often encouraged to be "more critical", or accused of not "critical enough". The Chinese students often have a lot of experiences in memorization, respecting and obeying teachers and elderly rules and opinions in China. They were often taught that their personal ideas do not matter.

\subsection{Studying Abroad Experiences}

Literature also discusses whether the Chinese students' difficulties in problem-solving can be attributed to the lack of critical thinking. To some extent, the "problem-solving skill" itself is a vague term. Various projects have demonstrated that "problem-solving" involved a variety of skills based on the contexts of the problem, for instance, looking for the sources, asking for advices, framing and reframing the problems, or in some situations, even the ability to circumvent the problem and avoid the problems (Johnston et al, 2013).

Some literature defined problem solving as part of the critical thinking (McGuiness, 2005). Critical thinking is essential for problem-solving since critical thinking helps enhance the students' understanding of the problems and making judgements about whether the information is true or false, and reach a conclusion for the solution (Hyytinen et al, 2014). At the same time, critical thinking entails problem-solving as a critical thinker needs to open-mindedly seek information and find answers.

The Chinese students, however, exhibit surface approach to a greater extent than the Finnish students (Sakurai et al, 2014). Sakurai et al also pointed out that such result is tentative if considering the difference between Chinese and Western students' styles to respond to the surveys (Van Herk et al, 2004 as cited in Sakurai et al, 2014). Other study examining the deep and surface approaches to problem solving in Chinese students' experiences reported conflicted results. While some studies argue that Chinese students' preference to surface learning approach was a result of the examination-oriented education system they are so used to in China, rather than Chinese culture, other studies found that after the Chinese students studied in the Western universities, the Chinese students still favoured surface learning approach (Kember, 2000) and therefore, it is a result of Chinese culture and upbringing rather than the educational system.

\section{METHODS}

This section introduces the sample, the data collection method and analysis method. As a qualitative study, this study uses interviews to collect Chinese students and faculty's opinions on "critical thinking". This study is conducted in Westie (pesudonym) university, a comprehensive research university located on the East coast, U.S.A.

\subsection{Participants}

This study comprised of interview with 12 Chinese college students in their first and second year in engineering major and 10 faculty members from engineering major. An invitation was sent out through the International student service to recruit the participants. Some participants suggested other volunteers in the interviews, thus, this study used a snowballing method in participants recruitment. All of the faculty were nominated by the students. Among the 12 student participants, 6 were males, 6 were females.

\subsection{Interviews}

The data collection is comprised of two parts 1) face to face one on one interview; 2) follow up emails. The interviews were conducted within a semester. Interviews have been widely used in qualitative data collection both in education and in sociology to understand participants' opinions and experiences. The interviews were designed and conducted following Charmaz's (2006)'s method for data collection and data analysis using grounded theory approach. In this kind of data collection, researchers should design a few broad, openended questions, and then when it is appropriate, ask for more details depending on the participants' reactions to the questions. The student interviews were conducted individually in face-to-face and one-on-one manner and all the interviews were audio-recorded with the participants' permission. All the faculty and students are from engineering major, including mechanical engineering, chemistry engineering, Applied Math etc. All the interviews lasted from 30 minutes to an hour for both students and faculty interviews. I understood that using students' recommendation in faculty interview recruitment might be biased towards the highly motivated faculty who were more devoted to teaching and have higher interests in critical thinking than average. However, data shows that even this group of highly motivated faculty have difficulties understanding the Chinese students. The faculty's opinion in this kind of data set might not be representative of all US faculty in each university. 


\subsection{Analysis}

All the interviews, conducted in Chinese language, were transcribed by the author. To analyse the data, the author used a constructivist grounded theory approach (Charmaz, 2011). The authors went through three rounds of coding procedure to code and analyze the data.

\section{RESULTS}

\subsection{Faculty's Opinions on Critical Thinking Concept in Engineering Major}

12 U.S. faculty in the Westie university volunteered to offer their opinions in "critical thinking" concept and Chinese students' learning experiences in engineering school. Most of the U.S. professors interviewed for this project emphasized that critical thinking concept has to be transferred and connected with some concept in engineering major. Seven out of 12 professors offered their definition of "critical thinking". For them, "critical thinking" is a skill to apply a number of cognitive moves, for instance, "higher order thinking" such as being able to solve a problem in an engineering study, being able to analyse pros and cons of using different methods in problem solving, or being able to synthesis different theories and produce an answer or self-reflect on their own usages of engineering methods or study. The other four professors $(40 \%)$ discussed ideas such as human rights, deconstruction, or students' subjective opinions as definitions of critical thinking.

First of all, a mechanical engineering professor defined critical thinking as to analyze the deviations to the lab result and being able to analyze the problems happened in the lab work. Students in engineering major have to understand the theories and using the theories to understand the deviations. Then, he reported in the interview that he discussed Dalton's atomic theory discovered 200 years go with his students. He wanted his students to appreciate the development and progress of science and also to understand the limitation of science and specifically, what does science mean to human development.

Here, the deviation to a lab result is the subjects to be analyzed in the chemistry lab contexts. Specifically, the subject of analysis is all the possibilities of deviations in the lab.

Professor Wilson who teaches an entrance level chemistry course also mentioned several concepts other than higher order thinking skills that can be associated with critical thinking. He defined critical thinking around the idea of "philosophy of science".
First of all, he didn't believe that critical thinking is that important as he teaches in an entrance level chemistry class for engineering students. For him, most of the problems have been solved before and there weren't really much critical thinking involved in those. What's more, Professor Wilson talked about Dalton's atomic theory which was discovered 200 years ago. He wanted students to understand the development and the progress of science, and to know the limitation and meaning of such scientific discoveries and progress. But in terms of writing a paper about Dalton and what they (the students) think about it, the professor had never required his students to do that in science class. It is out of his scope of teaching.

In Professor Wilson's answer, critical thinking can be quite a few different ideas: Discussing the philosophy of science; the understanding of historical contexts and development; as he emphasizes "we know a little bit more", and the previous theory was "a little bit wrong", he seemed to suggest that being a scientist means understanding that there are a lot about science that is unknown and scientists have to live with this unsureness.

From the two interviews above, we can see that while faculty recognize and understand the importance of critical thinking, they do not believe that critical thinking is so important in engineering major.

\subsection{Chinese Engineering Students' Experiences of Critical Thinking Concept}

This study interviewed a Chinese mechanical engineering student in his fourth year study named Song. He conceptualized critical thinking as analytical skills and problem solving in his mechanics engineering classes, especially design classes which he enjoyed a lot.

Song: In mechanics engineering, critical thinking means analyze the mechanical problems and choose the right principles to solve those problems. Sometimes you need to evaluate and synthesize.

In Song's example, critical thinking is analytical and problem solving skills situated in mechanics engineering context-choosing the right principal to solve engineering problems.

However, if you compare Song's concept of critical thinking, in other words, solving mechanical problem as critical thinking, to some of his professors. There is a difference between their opinions. Some professors believe that the problems solved by the undergraduate students are not invented by the students, nor the method to solve the problem. In the professors' opinions solving mechanical problem at undergraduate level is not critical thinking. According to some U.S. 
engineering professors, the students have to "invent something" to demonstrate critical thinking. Thus, there are differences in understanding definitions of critical thinking between the faculty and the students.

\subsection{Understanding Critical Thinking in Learning}

While some U.S. professors do not believe that solving undergraduate level engineering problems may involve any critical thinking, those professors believe that when the students got to higher level in engineering, those work involve critical thinking. Those professors specifically discuss that when the students get to higher work, there are choices to make and students have to make personal judgement. The problems they solve do not have a standard answer. Thus, there are elements that the students have to make some inventions based on their judgement and not totally learning about the rules and regulations. In those professors' opinion, critical thinking is all about "personal judgement". In mechanical engineering, such judgement comes with preliminary knowledge and backgrounds.

One element about Chinese students' experiences were not mentioned by the mechanical engineering professors. Chinese students in engineering believed critical thinking is important in social science courses they took, for instance, the courses regard sociology, extensive reading and writing. Compared to those courses, the professors focused on having the students get the right answers rather than critical thinking in other courses like economics, business, science and engineering courses:

Changsu (Chemistry Engineer): The course that develop my critical thinking are mostly psychology, and geography...In STEM majors, the work tends to have a correct answer... You have to understand the textbooks in order to solve those problems but you don't really question your textbook or so. You just follow it. Geography and sociology often dealt with controversial issues that involves personal opinions and thus, you have to question, and you have to have your own opinions. There are not that many rules to memorize and follow.

Here, critical thinking is situated in the opportunities to state his personal opinions in social science classes. Changsu stated that he enjoyed taking sociology or geography which asked for his personal opinions and contributed to his personal development. However, he did not feel critical thinking is nurtured for his STEM courses which are important for his job hunting.

In engineering, another issue that mentioned by a number of faculty and students are their experiences that Chinese students work with American students. Some professors specifically mention that a student with critical thinking ability should be willing to work students of different cultural backgrounds. However, the Chinese students often did not speak highly about working with American students. Actually, several Chinese students described that working with American students in groups were hard for them.

One mechanical engineering students reported that his grade for the senior design project was bad because he had difficulties cooperate with American students in his group. They had different opinions in terms of his contribution to the project. For the professor's perspective, he was only involved in doing the calculation and was not involved in designing the new tool they were making. However, according to this student, the problem was that he lacked effective communication strategy to work with his classmates. Song failed to convince his group members to work on his idea. In the initial stage, he believed he had creative ideas in terms of the design. However, there are several people in his group and everyone wants to push his own idea. In the end, his idea was not adopted in the group. Actually, it is common for engineers to work in group, but communication skill in group work is not sufficiently addressed in engineering education. People tend to take it for granted that good ideas will work out.

Song's experience show that critical thinking is not a cognitive skill that is only about analysis, problem solving or even being creative and having a personal opinion. Quite contrary, critical thinking is very much about whether the student's ideas were recognized by the faculty, by the peers, or whoever making the judgement of critical thinking and whether the student was able to push for his own ideas. The Chinese student in the case above did not lack creativity in working in a design project, but he was not familiar with enough negotiation strategy in American colleges to push his idea forward and win over his peers to work on his idea. In the end, he was evaluated as lack of critical thinking.

Working with American students proves to be a headache for many Chinese students in various different ways. However, none of those ways were connected to the Chinese students' cognitive skill although those incidences were often interpreted as Chinese students' lack of critical thinking. One Chinese student reported in the interview that working with American students was stressful and often leads to problems about interperson relationship rather than cooperation. According to him, he often met problems when he was working with American students.

I don't know what exactly should I do when I work with American students. When I was running late for a group work, what should I do? What if I can't figure out the work that is assigned to me? What if I have time conflicts? 
In conclusion, Chinese students reported a variety of difficulties they ran into while working with American students in group work in engineering major.

\section{DISCUSSIONS}

This paper finds that the Chinese students' perceptions of critical thinking in engineering program might be different from their faculty or from literature in critical thinking. While literature traditionally emphasizes "critical thinking" as an higher order thinking skills (McGuinness, 2005), engineering faculty and students have different perceptions in terms of "the subject of analysis". However, some Chinese students, they believed an analysis of problems or situations as "critical thinking". Secondly, as to the importance of critical thinking, unlike previous belief about the importance of critical thinking (Johnston et al, 2011), several professors stated that they do not perceive critical thinking as important for entry level engineering education. The Chinese students, on one hand, perceive that "critical thinking" is not much involved in entrance level engineering education; on the other hand, perceive that they need to take human science classes in colleges to obtain "critical thinking" for their personal growth.

Thirdly, the U.S. professors pointed out several kinds of performances of the Chinese students that were deemed as "lack of critical thinking" by the professor. The Chinese students, however, believe that group work inhibited their ability to demonstrate critical thinking because they were not familiar with the academic convention of group work. They were confused about rules of working with American and felt that they had to exert extra effort when working with Americans and those effort could be more sufficiently spent on academic issues.

\section{CONCLUSION}

Thus, this article provide evidences that dispute popular beliefs about critical thinking in engineering education, especially the Chinese international students in engineering education. This article has implications about engineering education. Engineering education may has its unique position in nurturing students' critical thinking due to the specialty of this discipline

\section{REFERENCES}

[1] Heng, T. T., Different is not deficient: Contradicting stereotypes of Chinese international students in US higher education. Studies in Higher Education, (2016) 1-15.

[2] Watkins, D. A., \& Biggs, J. B., The Chinese learner: Cultural, psychological, and contextual influences, ERIC, 1996.
[3] Johnston, B., Ford, P., Mitchell, R., \& Myles, F. Developing student criticality in higher education: Undergraduate learning in the arts and social sciences. Bloomsbury Publishing, 2011.

[4] Glaser, E. An experiment in the development of critical thinking. The Teachers College Record, 43(1942), 409-410.

[5] Davies, M., A model of critical thinking in higher education, Higher education: Handbook of theory and research pp. 41-92, Springer, 2015.

[6] Dong, Y. Critical thinking education with Chinese characteristics. The Palgrave handbook of critical thinking in higher education. Springer, 2015, pp. 351-368.

[7] Moore, T. Critical thinking: Seven definitions in search of a concept. Studies in Higher Education, 38(2013) 506-522.

[8] Fox, H, Listening to the world: Cultural issues in academic writing. Urbana, IL: National Council of Teachers of English, 1994.

[9] Kettle, M., \& Luke, A. The critical meets the cultural: International students' responses to critical, dialogic postgraduate education in a western university. In S. Sovic \& M. Blythman (Eds), International Students Negotiating Higher Education: Critical Perspectives. P.104-123 Routledge. 2013.

[10] McGuinness, C. Teaching thinking: Theory and practice. BJEP monograph series II, number 3pedagogy-teaching for learning p.107-126, British Psychological Society, 2005.

[11] Hyytinen, H., Holma, K., Toom, A., Shavelson, R. J., \& Lindblom-Ylänne, S., The complex relationship between students' critical thinking and epistemological beliefs in the context of problem solving. Frontline Learning Research, 2(2014), 125.

[12] Sakurai, Y., Parpala, A., Pyhältö, K., \& LindblomYlänne, S., Engagement in learning: A comparison between Asian and European international university students. Compare: A Journal of Comparative and International Education, 46(2016), 24-47.

[13] Kember, D., Misconceptions about the learning approaches, motivation and study practices of Asian students. Higher Education, 40(2000), 99121.

[14] Charmaz, K. Constructing grounded theory. London: Sage. Aderhold J, Davydov V Yu, Fedler F, Klausing H, Mistele D, Rotter T, Semchinova O, Stemmer J and Graul J 2001 J. Cryst. Growth 222 $701,2014$. 